\title{
ARTICLES
}

Submitted 09.06.2012. Approved 07.02.2013

Evaluated by double blind review. Scientific Editor: Bento Alves da Costa Filho

DOI: http://dx.doi.org/10.1590/So034-759020140206

\section{MULTILEVEL AND MULTIDIMENSIONAL SCALE FOR ONLINE TRUST}

\author{
Escala multinível e multidimensional para confiança online \\ Escala multinivel y multidimensional para la confianza en línea
}

\section{MARIA JESÚS LÓPEZ MIGUENS chusl@uvigo.es Professor at Departament of Business Management and Marketing, University of Vigo, Vigo - Spain}

\section{ENCARNACIÓN GONZÁLEZ VÁZQUEZ egzlez@uvigo.es \\ Professor at Departament of Business Management and Marketing, University of Vigo, Vigo - Spain}

\section{PALOMA BERNAL TURNES}

paloma.bernal@urjc.es Lecturer at Departament of Business Management, Rey Juan Carlos University, Madrid - Spain

\begin{abstract}
This paper examines the nature of the construct of consumers' trust toward the electronic channel of their financial institution. Through a study of a total of 372 individual users of Internet banking in Spain, we have managed to develop a third-order measuring instrument that integrates a total of seven dimensions. The exploratory and confirmatory factor analyses were used to test the validation and reliability of the proposed scale. Findings provide useful information to professionals who seek to identify how customer's trust is formed in the online channel and in the financial sector.
\end{abstract}

KEYWORDS | Scale, trust, online banking, users, validation.

\section{RESUMO}

Este artigo analisa a natureza do construto- confiança dos consumidores em relação ao canal eletrônico de sua instituição financeira. Por meio de um estudo com 372 usuários individuais de operações bancárias via internet na Espanha, conseguimos desenvolver um instrumento de medida de terceira ordem que integra sete dimensões. Foram utilizadas análises fatoriais exploratórias e confirmatórias a fim de testar a validade e a confiabilidade da escala proposta. Os resultados fornecem informações úteis aos profissionais que procuram identificar como se constitui a confiança do cliente no canal online e no setor financeiro.

PALAVRAS-CHAVE | Escala, confiança, operações bancárias online, usuários, validação.

\section{RESUMEN}

Este trabajo examina la naturaleza del constructo confianza de un consumidor hacia el canal electrónico de su entidad financiera. A través de un estudio efectuado sobre un total de 372 usuarios particulares de la banca en Internet en España se ha conseguido desarrollar un instrumento de medida de tercer orden formado por un total de siete dimensiones. Los análisis factoriales exploratorio y confirmatorio han sido las herramientas utilizadas para efectuar las pruebas de validación y fiabilidad a la escala propuesta. Las conclusiones del estudio proporcionan información útil a los profesionales que persiguen identificar cómo se forma la confianza del cliente en el canal y sector referido.

PALABRAS CLAVE I Escala, confianza, banca electrónica, usuarios, validación. 


\section{INTRODUCTION}

As a similar trend has occurred in countries with closed economies, the Spanish banking sector has experimented significant changes over the last decades, such us the increase of the banking activity, deregulation, disintermediation or introduction of new technologies (Perez \& Maudos, 2001; Carbó, 2004; Bravo, Montaner \& Pina, 2007; Garrido, 2007). In particular, the incorporation of Internet in the financial sector has led to substantial implications at an economic level, changes in the way firms' activities are developed and has dramatically changed the daily lives of customers. Thus, related to companies, the investment in information technologies has led to a reduction in labour costs and a set of improvements in efficiency, productivity and business performance (Bitner, Zeithaml \& Gremler, 2010; Dabholkar, 1996). Internet has also enabled the development of alternative distribution channels to the traditional offices-based one (cashier, phone banking, and electronic banking) and favours the entry of other financial and non-financial institutions in the banking sector, this last situation has further enhanced the level of competition (Garrido, 2007). Related to the banking consumers' behaviour, these consumers are increasingly educated and demanding (Alcaide \& Soriano, 2005) and they have seen the advantages of convenience, independence and quality (Oliver, Livermore \& Farag, 2009; Carbó, 2004; Gerrard \& Cunningham, 2003; Meuter, Ostrom, Roundtree \& Bitner, 2000) as determinants for the adoption of the medium. At the same time, the lack of consumer trust in the financial service provided by online banks has been argued to be one of the most important barriers to developing the potential of the electronic banking (Gefen, 2000; Jarvenpaa, Tractinsky \& Vitale, 2000; Yoon, 2002; Chouk \& Perrier, 2004; Harris \& Goode, 2004), due to the perception of high risk by Internet when carrying out certain transactions over the Internet.

This situation has prompted a growing number of theoretical and empirical researches in order to study the construct of trust in the electronic banking. However, trust has been understood in different ways in terms of composition and dimensions (see Cheung \& Lee, 2006). These works have been developed from the firm's perspective (supply) neglecting the perspective of the consumers, whose perception enhances the success of a firm (Bravo, Montaner \& Pina, 2007).

According to the above mentioned motives, banking strategies should be defined based on the identification of all indicators that are involved in the building of customer trust over the Internet in order to reduce risk. So, the aim of our work is to deepen on the understanding of a more effective strategic mix that defines the marketing efforts to build online trust in a financial busi- ness that uses the electronic channel. With the development of a measurement scale from the perspective of customer's perception, we try to understand how the trust of users who utilize electronic services of a financial institution is explained.

The article is structured as follows. The first section discusses the theoretical principles based on the conceptualization of the construct and then we formulated the measuring instruments of online trust. In the second part, the measurement scale developed is tested at different levels with regard to the dimensionality, reliability and validation, in both exploratory and confirmatory terms. The third section highlights the conclusions and managerial or scientific implications of the obtained results. The article concludes with the presentation of the main limitations of the research.

\section{THEORETICAL AND CONCEPTUAL FRAMEWORK}

The term trust plays a key role in explaining the online consumers' behaviour (Pavlou, 2003). Since ancient times, trust has been investigated in the marketing literature; however, Das and Teng (2004) argue that, despite being one of the most used terms in the social sciences, it is the "least understood" of the most important concepts of the discipline.

Building and maintaining trust in the online distribution channel is more important (Sultan \& Mooraj, 2001; Gefen, Karahanna \& Straub, 2003; Gefen \& Straub, 2004; Walczuch \& Lundgren, 2004; Riegelsberger, Sasse \& McCarthy, 2005; Harridge-March, 2006; Pavlou \& Fygenson, 2006) than in an offline environment. The online context entails greater difficulties (Grewal, Lindsey-Mullikin \& Munger, 2003; Reichheld \& Schefter, 2000; Bhattacherjee, 2002) and the degree of uncertainty is greater (Grabner-Krauter, 2002). In addition, the peculiarities of online banking enhance the importance of trust (Grabner-Kräuter \& Faullant, 2008), and distrust is one of the main reasons, stated in the recent literature, that justify the fear that users still show when conducting financial transactions over the Internet (Mukherjee \& Nath, 2003; Rotchanakitumnuai \& Speece, 2003; Luarn \& Lin, 2005; Flavián \& Guinalíu, (2006a). Hence, this lack of confidence can be enhanced if the user does not know "in depth" the company (Cheung \& Lee, 2006), if he or she is not familiar with the network, or if the user has suspicion towards the technology or the features that define the personality of the individual (Ruiz, Izquierdo \& Calderón, 2007).

In the large body of literature on the construct trust authors highlights the lack of unanimity about the definition of the term that has been "explained in a very vague and unsys- 
tematic way", despite the relevance of the concept (Cheung \& Lee, 2006). Numerous definitions have been proposed, some of them are coincident, but most picks up one or more specific aspects. In this study, we understand online trust reflects the extent to which a banking online user expects an honest, benevolent and competent behaviour of the company and company will cover measures in order to reduce insecurity and lack of privacy.

\section{DATA COLLECTION}

A structured questionnaire, completed electronically, was used to collect data. It has allowed us to collect a total of 578 responses of individual users of online banking, of which 372 have been found valid after a depuration process. Table 1 presents the data sheet of the investigation.

\section{TABLE 1. Technical details of the investigation}

\begin{tabular}{l|l}
\hline Sampling unit. & $\begin{array}{l}\text { Individual 16 to 74 years, resident in } \\
\text { Spain and users of online banking. }\end{array}$ \\
\hline $\begin{array}{l}\text { Geographical scope of } \\
\text { the study }\end{array}$ & Spain \\
\hline Sampling procedure. & $\begin{array}{l}\text { Non-probabilistic method. Convenience } \\
\text { sampling. Snowball }\end{array}$ \\
\hline Sample size (n) & 372 \\
\hline $\begin{array}{l}\text { Method of collection of } \\
\text { information }\end{array}$ & $\begin{array}{l}\text { The information was collected through } \\
\text { structured questionnaires, self- } \\
\text { administered electronically }\end{array}$ \\
\hline Dates of fieldwork & November 2008 to February 2009 \\
\hline $\begin{array}{l}\text { Number of } \\
\text { questionnaires }\end{array}$ & 518 \\
\hline
\end{tabular}

Results of data analysis shows that the profile of the user of online financial services is: young, male or female, with a high level of education and income, he/she accesses to the Web every 7 days or more often to see extracts, balance reporting or movements, or to make a transfer.

\section{MEASUREMENT SCALE}

According to the literature reviewed, the construct of trust in the electronic context includes general and specific attributes. General attributes refer to the part in which you trust and they are present in a traditional buyer-seller relationship, and specific attributes refer to the online context. Those general attributes shape trust as reliability and belief, according to the perspec- tive of social psychologists (Cheung \& Lee, 2006), and correspond with the first moment of trust, according to Ramón and Martin (2007). The specific attributes of online context are security and privacy.

Reliability refers to the perception that one person has about the dignity of another subject. In order to describe the reliability of the seller (object of trust), customer (partner who trusts) makes an analysis of certain characteristics and behaviours that seller could developed in the future (Ganesan, 1994; Coulter \& Coulter, 2002; Das \& Teng, 2004; Ramón \& Martin, 2007). However, despite the absence of a unified approach to establish what should be the attributes or dimensions that an individual must meet to be considered reliable (Ramón \& Martin, 2007), from the review we include three dimensions of trust: honesty, benevolence, and competence. Despite the condition of interpersonal relationship defended by Grabner-Kräuter and Faullant (2008), in the dimensions of benevolence and honesty, it is not strictly adhered to in the context of online banking; we opt for including these dimensions because we understand users feel that not only does the technology participate in the relationship, but a group of people of the financial entity also do it.

Honesty arises from an evaluation process and refers to the conviction that consumer shows respect to sincerity and the degree of fulfilment of the promises the other party made (Anderson \& Narus, 1990; Gundlach \& Murphy, 1993; Doney \& Cannon, 1997; Geyskens, Steenkamp \& Kumar, 1998, 1999). Benevolence is strongly related to the goodwill of the seller. Thereby, a company will be considered benevolent during the exchange whether it seeks the correct development of the exchange rather than corporate profits (Lee \& Turban, 2001; Belanger, Hiller \& Smith, 2002). Benevolence has been measured by searching consumer welfare (Crosby, Evans \& Cowles, 1990; Ganesan, 1994; Doney \& Cannon, 1997; Cheung \& Lee, 2006; Flavián \& Guinalíu, 2007), obtaining a joint benefit (Doney \& Canon, 1997), as well as avoiding opportunistic behaviour (Larzelere \& Huston, 1980), and so on. Competence of the company is also measured through the perceptions of customers. They assess whether the company has the skills (Blomqvist, 1997), abilities and characteristics (Cheung \& Lee, 2006) required to make something that has been previously promised. This attribute is particularly important in the electronic context (Roy, Dewit \& Aubert, 2001; Bhattacherjee, 2002; Pavlou, 2003; Suh \& Han, 2003), because seller should prove that has the needed resources to accomplish that with what has been committed in a safe and efficient way (Flavián \& Guinalíu, 2007).

Based on the literature review, the indicators and authors proposed to explain the construct reliability (Table 2) are summarized. 
TABLE 2. Proposed instrument for measuring the reliability (honesty, benevolence and competence) of online banking

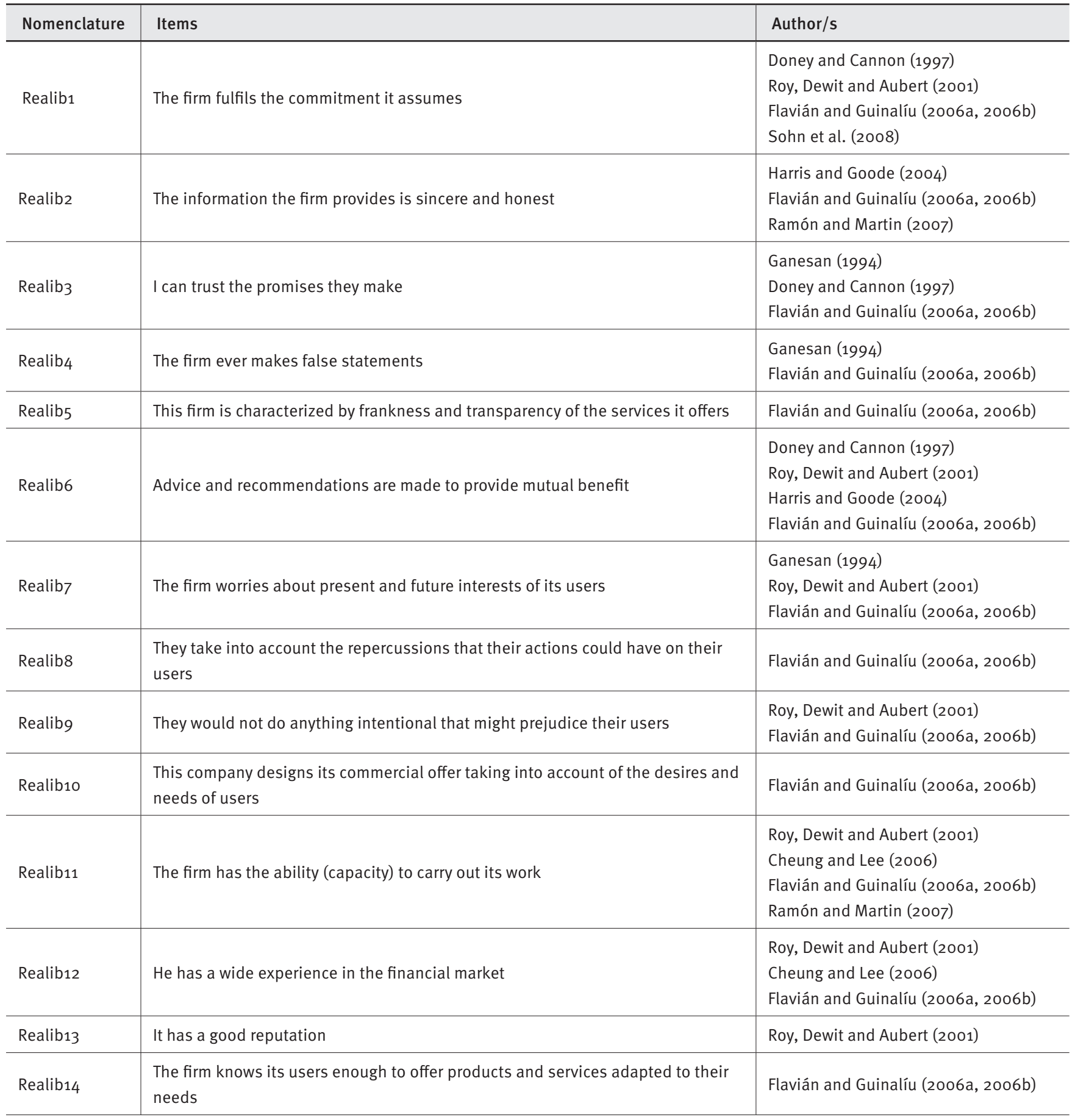

Particularities of the channel indicate specific measures are needed to approximate online trust, in order to consider comprehensively the security condition in the medium. Unlike the traditional channel, consumer's behaviour over the Internet is recorded from accessing the Web and throughout the navigation process. Related to this fact there are two aspects that exceptionally worry users: security and protection of the privacy in treatment of private data. Although they are related, these two criteria have been used separately in the literature (e.g., Keeney, 1999; Ranganathan \& Ganapathy, 2002). This has led us to propose two dimensions in our research: security and privacy.

The first dimension refers to technical aspects of the security of information systems on which data protection measures are based. According to Kolsaker and Payne (2002) se- 
curity includes the mechanisms of transmission and storage of information. Security mechanisms are: digital signature, utilizing platforms of data encryption, certificates of a safe connexion, creating secure passwords, utilizing authentication and access control mechanisms, and so on. The second dimension, privacy, refers to the process of protecting users' data against accidental or voluntary transfer to third people or entities to which users have not actually allowed their data to be used, modified or destructed (Udo, 2001). Companies could respect their users' privacy by not providing personal information to other sites, protecting their anonymity, and requesting users their consent (Friedman, Kahn \& Howe, 2000). Table 3 shows the items we have used to create the second-order construct of security in the medium, its description and authors who have integrated them into their measurement scales exactly or in an adapted way.

\section{TABLE 3. Proposed instrument for measuring the security in the Internet medium}

\begin{tabular}{|c|c|c|}
\hline Nomenclature & Items & Author/s \\
\hline Sec-Med1 & The firm implements security mechanisms to protect users & $\begin{array}{l}\text { Cheung and Lee (2006) } \\
\text { Flavián and Guinalíu (2006a) } \\
\text { Grabner-Kraut and Faullant (2008) }\end{array}$ \\
\hline Sec-Med2 & $\begin{array}{l}\text { The information of a transaction is protected from disturbance during a } \\
\text { connection }\end{array}$ & $\begin{array}{l}\text { Parasuraman, Zeithaml and Malhotra (2005) } \\
\text { Cheung and Lee (2006) }\end{array}$ \\
\hline Sec-Med3 & It has a safety system of identification of users (service access) & Cheung and Lee (2006) \\
\hline Sec-Med4 & $\begin{array}{l}\text { The firm do not sell my personal information to other organization without } \\
\text { my permission }\end{array}$ & Cheung and Lee (2006) \\
\hline Sec-Med5 & The firm shows concern for the privacy of its users & $\begin{array}{l}\text { Cheung and Lee (2006) } \\
\text { Flavián and Guinalíu (2006a) }\end{array}$ \\
\hline Sec-Med5 & The firm does not disclose users' personal information to others & $\begin{array}{l}\text { Gerrard and Cunningham (2003) } \\
\text { Parasuraman, Zeithaml and Malhotra (2005) } \\
\text { Cheung and Lee (2006) } \\
\text { Flavián and Guinalíu (2006a) }\end{array}$ \\
\hline
\end{tabular}

Based on the above insights, we propose a third-order construct of online trust with two second-order dimensions: reliability (formed by honesty, benevolence and competence) and security in the Internet medium (formed by security and privacy).

\section{The measurement scale development}

In order to reduce as far as possible the errors of measurement, the development of the measurement scale was based on assessing the compliance of its psychometric properties. The process has been developed in 5 stages: content validity, one-dimensionality, reliability and convergent and discriminatory validity.

Content validity. The first revision to the validity of the scale is applied to the conceptual content. According to the reviewed literature and a group of experts, it has been checked that the scale reflects all aspects of the term that represents and considers the context. As a result of this process, a set of 20 total items has been generated.

One-dimensionality. As the second stage, the scale has been refined in relation to its dimensionality, using an exploratory factor analysis (EFA) and a confirmatory one (CFA).

The first analysis was carried out on each of the 20 items proposed, applying principal components analysis with Varimax rotation. The significant factor loads should be higher than 0.30 , following the criterion indicate by Hair, Anderson, Tatham \& Black (1999) that attend to the size of the sample. Results of the factor loads obtained for analysis in second and third-order exceed the limit. In terms of commonalities, the assessment shows values above 0.50 , so all variables contribute to the explanation of the factor solution obtained. Consequently, we have generated a total of 5 dimensions, as shown in Table 4. 
TABLE 4. Exploratory analysis of one-dimensionality (second and third-order)

\begin{tabular}{|c|c|c|c|c|c|}
\hline Dimension & Item & \multicolumn{2}{|c|}{ Second level } & \multicolumn{2}{|c|}{ Third level } \\
\hline \multirow{3}{*}{ Honesty } & Reliab2 & 0.803 & 0.645 & 0.791 & 0.816 \\
\hline & Reliab3 & 0.740 & 0.766 & 0.709 & 0.837 \\
\hline & Reliab5 & 0.591 & 0.751 & 0.553 & 0.758 \\
\hline \multirow{3}{*}{ Benevolence } & Reliab6 & 0.714 & 0.726 & 0.711 & 0.729 \\
\hline & Reliab7 & 0.776 & 0.819 & 0.782 & 0.837 \\
\hline & Reliab10 & 0.762 & 0.618 & 0.750 & 0.800 \\
\hline \multirow{4}{*}{ Competence } & Reliab11 & 0.570 & 0.661 & 0.538 & 0.672 \\
\hline & Reliab12 & 0.835 & 0.819 & 0.790 & 0.819 \\
\hline & Reliab13 & 0.829 & 0.806 & 0.794 & 0.814 \\
\hline & Reliab14 & 0.655 & 0.638 & 0.632 & 0.758 \\
\hline \multirow[b]{2}{*}{ Security } & Sec-Med1 & 0.868 & 0.803 & 0.843 & 0.803 \\
\hline & Sec-Med 2 & 0.737 & 0.695 & 0.751 & 0.749 \\
\hline
\end{tabular}

From the results obtained at the exploratory analysis, we carried out a confirmatory analysis that allows us to accept or reject the proposed dimensions.

We began the analysis by estimating, using AMOS 7.0, a first-order model for each of the proposed dimensions. To identify the security and privacy models, the factor loadings secmed 1 and sec-med 4 have been fixed because they had provided the highest values in the EFA. We have assigned them the values that had been registered in this analysis. The initial models show adjustment values below the acceptable level for the dimensions: honesty, benevolence and competence (Table 5). The standardized chi-squared $\left(\chi^{2} / d f\right)$ of the three initial models was not between 1 and 5, which are the limits recommended by Hair, Anderson, Tatham and Black (1999). Neither do the values of RMSEA, NFI, CFI, GFI and AGFI show a good fit. RMSEA should be less than 0.08 (Steiger, 1990) and in the models shows values between 0.202 and 0.090 ; NFI is acceptable if it is over than 0,90 (Lévy \& Varela, 2003), and results show values between 0.794 and 0.871 ; CFI, recommended instead of chisquare for samples over 100 observations (Lévy \& Varela, 2003), should be close to 1 to reflect a good fit; GFI might be over than 0.9 (Jöreskog \& Sörbom, 1986), the first-order model match this condition and AGFI shows a good fit it is above 0.9 (Jöreskog \& Sörbom, 1986; Hair, Anderson, Tatham \& Black. 1999; Lévy \& Varela, 2003), this last criterion does not occur with the initial dimensions. The modification indices (MI), the offending estimates (Hair, Anderson, Tatham \& Black, 1999; Luque, 2000) and the SMC were reviewed, and the results recommend items reliab1 (in the honesty dimension), reliab6 (benevolence) and reliab12 (competence) were removed. The identification of the first-order model of competence has been done in accordance to the previous indications of the security and privacy scales. So, we have fixed the reliab13 value. The final first-order models show very good fit (see Table 5). 
TABLE 5. Adjustment fit measures (first, second and third-order)

\begin{tabular}{|c|c|c|c|c|c|c|c|c|c|c|c|c|}
\hline \multirow{2}{*}{ Dim. } & \multicolumn{2}{|c|}{$\chi^{2} / \mathrm{df}$} & \multicolumn{2}{|c|}{ RMSEA } & \multicolumn{2}{|c|}{$\mathrm{NFI}$} & \multicolumn{2}{|c|}{$\mathrm{CFI}$} & \multicolumn{2}{|c|}{ GFI } & \multicolumn{2}{|c|}{ AGFI } \\
\hline & initial & final & initial & final & initial & final & initial & final & initial & final & initial & final \\
\hline \multicolumn{13}{|l|}{ FIRST LEVEL } \\
\hline Honesty & 4.033 & 2.944 & 0.090 & 0.072 & 0.871 & 0.96 & 0.896 & 0.972 & 0.945 & 0.980 & 0.835 & 0.901 \\
\hline Benevol. & 5.651 & 1.924 & 0.112 & 0.050 & 0.866 & 0.976 & 0.884 & 0.988 & 0.941 & 0.991 & 0.824 & 0.953 \\
\hline Compet. & 16.131 & 0.395 & 0.202 & 0.000 & 0.794 & 0.996 & 0.799 & 1.00 & 0.907 & 0.999 & 0.535 & 0.993 \\
\hline Security & 0.211 & & 0.000 & & 0.997 & & 1.00 & & 0.999 & & 0.993 & \\
\hline Privacy & 1.049 & & 0.011 & & 0.988 & & 0.999 & & 0.994 & & 0.964 & \\
\hline \multicolumn{13}{|c|}{ SECOND LEVEL } \\
\hline Reliabil. & 3.260 & 1.268 & 0.078 & 0.027 & 0.717 & 0.952 & 0.778 & 0.989 & 0.865 & 0.979 & 0.783 & 0.947 \\
\hline $\begin{array}{l}\text { Security in } \\
\text { the medium }\end{array}$ & 3.195 & 2.053 & 0.077 & 0.53 & 0.843 & 0.930 & 0.881 & 0.962 & 0.923 & 0.964 & 0.798 & 0.893 \\
\hline \multicolumn{13}{|l|}{ THIRD LEVEL } \\
\hline Online trust & 1.625 & & 0.041 & & 0.860 & & 0.939 & & 0.933 & & 0.893 & \\
\hline
\end{tabular}

Furthermore, to guarantee the validity of these results, a bootstrap procedure using 500 random samples was applied. The results obtained are presented in table 6 . As can be seen, all parameters are significant.

TABLE 6. Parameters Bootstrap (first-order). Means and confidence intervals at $\mathbf{9 0} \%$

\begin{tabular}{|c|c|c|c|c|c|c|c|c|c|}
\hline & Reliab2 & Reliab3 & Reliab4 & Reliab5 & Reliab7 & Reliab8 & Reliab9 & Reliab10 & Reliab11 \\
\hline Estimate & 0.827 & 0.917 & 0.888 & 0.875 & 0.900 & 0.911 & 0.831 & 0.766 & 0.727 \\
\hline Lower & 0.782 & 0.870 & 0.864 & 0.836 & 0.872 & 0.887 & 0.775 & 0.719 & 0.653 \\
\hline Upper & 0.879 & 0.950 & 0.916 & 0.912 & 0.938 & 0.944 & 0.880 & 0.823 & 0.789 \\
\hline \multirow[t]{2}{*}{$\mathrm{p}$} & 0.004 & 0.004 & 0.004 & 0.004 & 0.004 & 0.004 & 0.004 & 0.004 & 0.004 \\
\hline & Reliab13 & Reliab14 & Sec-med 1 & Sec-med 2 & Sec-med3 & Sec-med 4 & Sec-med5 & Sec-med6 & \\
\hline Estimate & 0.755 & 0.862 & 0.851 & 0.740 & 0.766 & 0.951 & 0.884 & 0.927 & \\
\hline Lower & 0.714 & 0.813 & 0.772 & 0.683 & 0.712 & 0.928 & 0.841 & 0.899 & \\
\hline Upper & 0.795 & 0.903 & 0.888 & 0.809 & 0.804 & 0.970 & 0.924 & 0.951 & \\
\hline$p$ & 0.004 & 0.004 & 0.025 & 0.001 & 0.011 & 0.004 & 0.004 & 0.004 & \\
\hline
\end{tabular}

In the second-order, the initials models proposed to represent reliability and security in the Internet medium was re-specified, the items reliab5 (honesty), reliab9 and reliab10 (benevolence), reliab13 (competence) and sec-med4 (security in the Internet medium) were suppressed.

The review of the parameters (values of the covariance matrix lower than 2, fit measures and squared multiple correla- tion (SMC) whose values were between 0.572 and 0.914 ) of the proposed third-order model show that the model is good.

Consequently, the model is accepted and integrates five second-order dimensions (benevolence, honesty, competence, security and privacy) and two third-order dimensions (reliability and security-medium) as shown in the Figure 1. This model collects all the discussed factors in the conceptual framework. 
Figure 1. Measurement model (third-order) of online trust

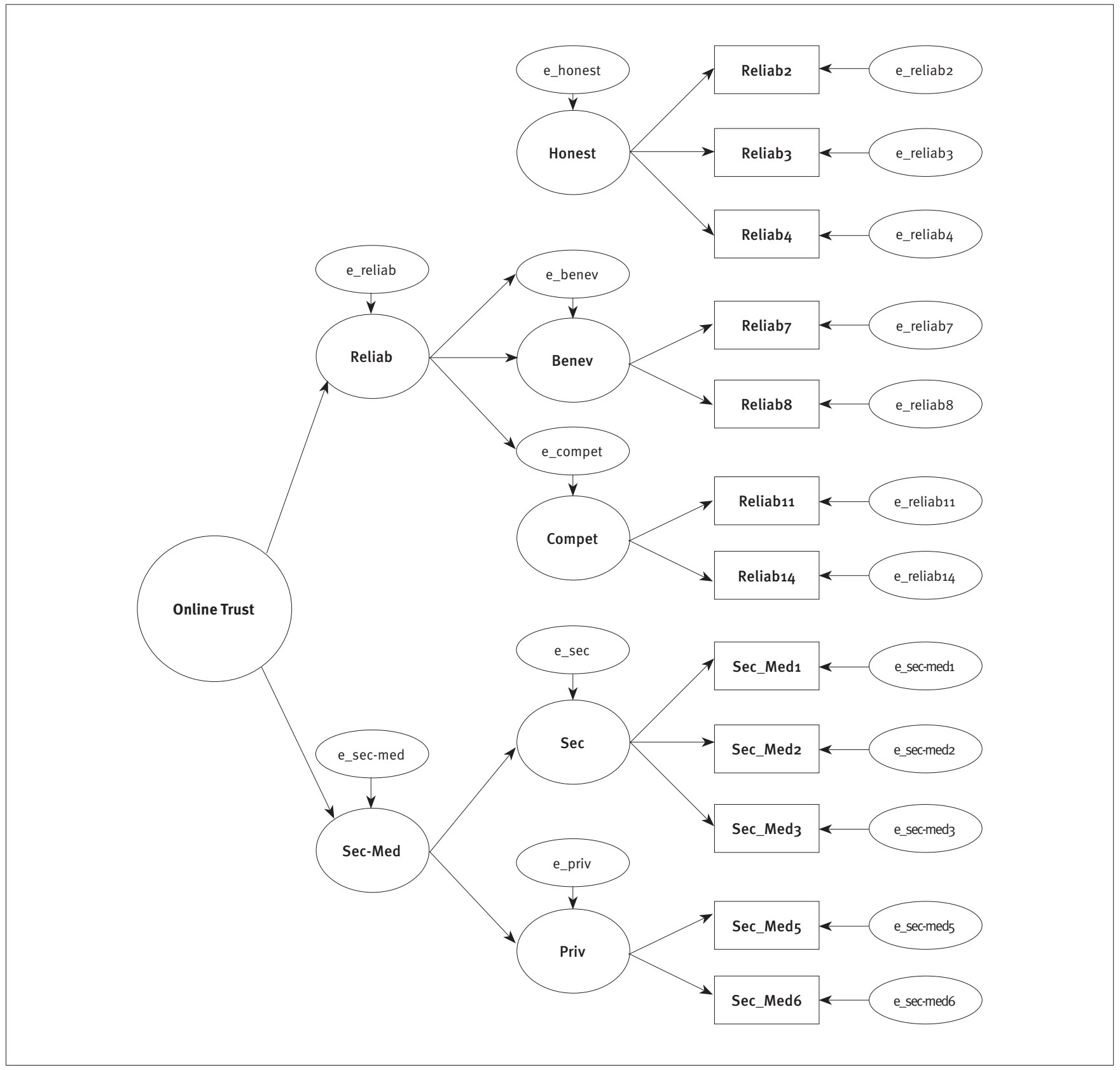

Consequently, results suggest the multidimensional and multilevel character of the construct of online trust, and the acceptance of the proposed dimensions.

Reliability. In order to confirm the reliability and consistency of the used indicators in each level of the scale, we use five measures: total item correlation, correlation inter-items, Cronbach alpha coefficient, composite reliability and AVE. Results are shown in Table 7.

All Cronbach's alpha coefficients exceed the minimum level set by 0.70 and it is not possible to improve the alpha removing any item. Those results show a high degree of internal consistency. On the other hand, the reliability measure based on the analysis of inter-item correlations is not strictly complied (in the third-order construct correlations are between 0.258 and 0.832 , in some cases they are below the limit of 0.3 established). After checking, the involved items were not removed from the analysis because their elimination did not improve the value of Cronbach's alpha (Alén, 2003). All item-total correlations exceed the value of 0.50 . With regard to the composite reliability and average variance extracted (AVE), statistical values significantly exceed in all cases the limit recommended of 0.7 (Luque, 2000) and 0.5 (Bagozzi, Yi \& Phillips, 1991), respectively. 


\section{TABLE 7. Reliability (exploratory and confirmatory level) of the scales (first, second and third-order)}

\begin{tabular}{|c|c|c|c|c|c|c|}
\hline & Cronbach's alpha & $\begin{array}{c}\text { Alfa possibility } \\
\text { improves }\end{array}$ & Inter-Item & Item-Total & $\begin{array}{c}\text { Composite } \\
\text { reliability }\end{array}$ & $\begin{array}{l}\text { Variance } \\
\text { extracted }\end{array}$ \\
\hline \multicolumn{7}{|l|}{ FIRST LEVEL } \\
\hline Honest & 0.904 & NO & & $\checkmark$ & 97.14 & 91.90 \\
\hline Benev & 0.908 & NO & $\checkmark$ & $\checkmark$ & $95 \cdot 71$ & 91.78 \\
\hline $\mathrm{Sec}$ & 0.823 & NO & $\checkmark$ & $\checkmark$ & 95.83 & 88.49 \\
\hline Priv & 0.905 & NO & $\checkmark$ & $\checkmark$ & 96.33 & 92.93 \\
\hline \multicolumn{7}{|c|}{ SECOND LEVEL } \\
\hline \multicolumn{7}{|l|}{ THIRD LEVEL } \\
\hline Online trust & 0.914 & NO & (0.258-0.832) & $\checkmark$ & 99.44 & 93.71 \\
\hline
\end{tabular}

Convergent validity. The measure of convergent validity estimates the extent to which the indicators of a construct or scale contribute to measure this construct. According to Lévy (2001), the factor loads of each indicator should be higher than 0.75 . The results of the analysis (Tables 8 and 9) allow us to confirm the convergent validity.

Discriminant validity. Discriminant validity measures the level of disagreement between two concepts or constructs (Hair, Anderson, Tatham \& Black. 1999). (Three tests were employed for testing empirically the discriminant validity (Table 10). The first test has an exploratory character and consists in assessing the correlations between constructs. If correlations have a value higher than 0.8 (Hair, Anderson, Tatham \& Black. 1999), (it may indicate that the variables measure a similar concept, although this must be checked from a confirmatory perspective. Two of the ten measured correlations between pairs of the second-order constructs have values around the limit: honesty and competence (0.83), and benevolence and competence (0.82). The following methods used have a confirmatory character. The first method, previously outlined by Fornell and Larcker (1981), consists of verifying that the square correlation between each pair of factors of a construct should be smaller than the variance extracted of their respective constructs. All of the pairs studied fulfil the condition, this demonstrates sufficient discriminant validity. Third, we applied the procedure described by Anderson and Gerbing (1988), so we calculate the confidence intervals of the correlation between the constructs and verify none of them contains the unit. This fact has also been contrasted; therefore, the discriminant validity of the measurement model is confirmed.

\section{TABLE 8. Convergent validity for the first-order scale}

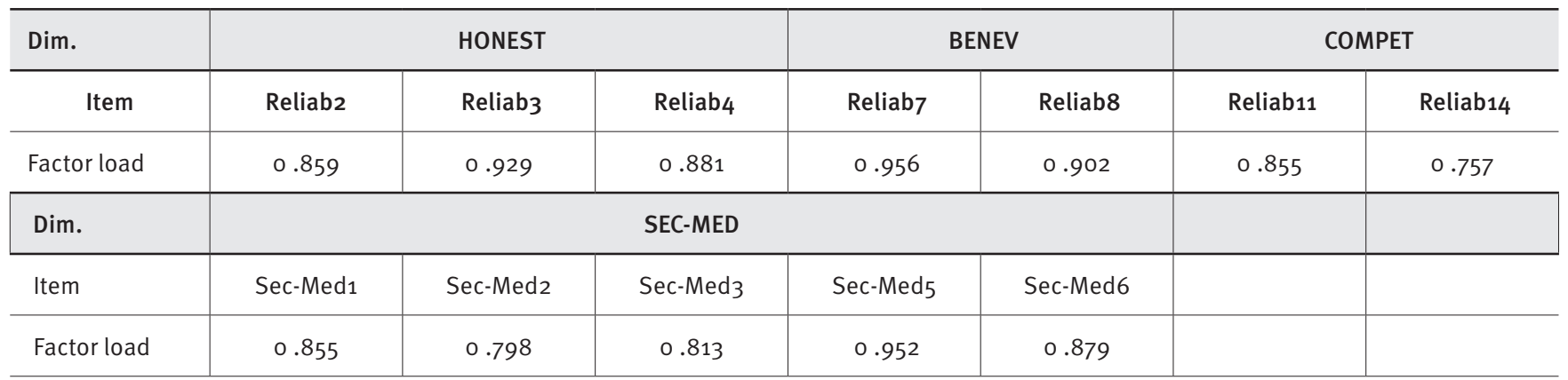


TABLE 9. Convergent validity for the second and third-order scales

\begin{tabular}{|c|c|c|c|c|c|c|c|}
\hline Dim. & \multicolumn{5}{|c|}{ SECOND-ORDER } & \multicolumn{2}{|c|}{$\begin{array}{c}\text { THIRD-ORDER } \\
\text { Online Trust }\end{array}$} \\
\hline Factor load & 0.900 & 0.890 & 0.956 & 0.825 & 0.889 & 0.762 & 0.777 \\
\hline
\end{tabular}

TABLE 10. Discriminant validity measures

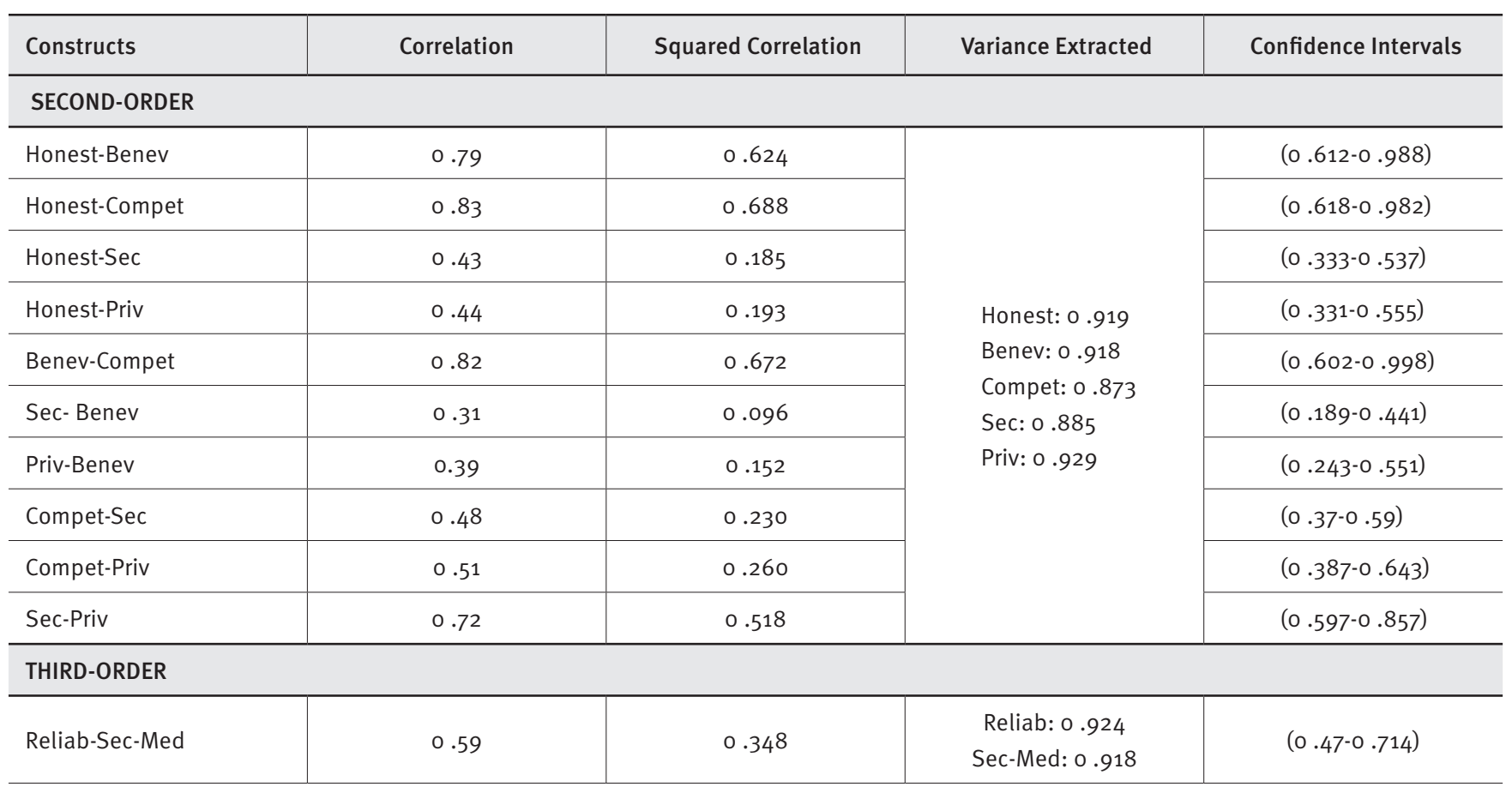

For all these reasons, we accept that the results obtained from the analysis satisfy the psychometric characteristics for the proposed scale.

\section{CONCLUSIONS AND MANAGERIAL IMPLICATIONS}

The aim of this study is to develop a scale to measure the trust of users in the online banking, to expand the current conceptualizations and to use it in future research. Compared to the found scales in previous studies, the developed scale contributes to the understanding of a concept that has been recognized as highly complex (Cheung \& Lee, 2006) and very important in the electronic context (Gefen, Karahanna \& Straub, 2003; Gefen \& Straub, 2004; Riegelsberger, Sasse \& McCarthy, 2005). To advance in the literature in which there is a lack of uniformity in the conceptualization and dimensionality with respect to this construct, we have developed a measure model that integrates a general dimension of trust and a specific dimension of the Internet channel.

Particularly, this paper presents two major contributions. First, we have developed a third-order scale for online trust in banking that shows good results in terms of dimensionality, reliability, and convergent and discriminant validity. In the literature, this variable has been conceptualized from both one-dimensional and multidimensional perspective (Grabner-Kräuter \& Faullant, 2008), but this last option is the most investigated. Most researchers have proposed a second-order factor model (for example, Flavián \& Guinalíu, 2006a; Battacherjee, 2002) but we have not found any study that proposes a third-order construct. In our study we have confirmed the multilevel and multidimensional character proposed of online trust. Thus, it is designated a third-order construct, divided into two second-order factors: reliability of online seller, and security and privacy policies on the Internet. These factors raise five sub-dimensions that participate in the evaluation of users about the online trust of the com- 
pany. Reliability is explained through honesty (related to users' belief that seller fulfils the promise he/she assumes and the accuracy of the provided information), benevolence (related to the willingness of the company that avoids opportunistic behaviour and seeks the users' welfare), and competence (related to the firm's ability and knowledge to support its commercial offer). Security in the medium consists of the dimensions of security (linked to security systems installed that prevent or mitigate possible errors and fraud during the electronic connection) and privacy (referred to the application and transmission of practices in order to protect the privacy of the personal data that are transferred during the transaction).

The second contribution is the inclusion of the dimension of channel security in the scale of online trust, since we have not found any study that has done it previously in the context of Internet banking. So, we consider that the consumer searches not only trust in the business (Harris \& Goode, 2004; Cheung \& Lee, 2006) but also trust in the Internet channel (Kini \& Coobinch, 1998; Novak, Hoffman \& Yung, 2000). Most of researchers use general factors that can be applied to any environment but not specifically from the electronic environment. From a review of the specific literature, the main dimensions of online trust are: honesty, competence, and benevolence (for instance, Torres, Manzur, Olavarrieta and Barra (2009), in the Latin America context and Casaló, Flavián and Guinalíu (2007) in the Spanish one). For their part, Grabner-Kraüter and Faullant (2008) in Austria, consider that "the technology itself has to be considered as an object of trust and they have been limited to measuring Internet trust for the online banking through four items related to perceived reliability and predictability of the Internet, and the willingness to depend on the Internet. In this context, other authors such us Casaló, Flavián and Guinalíu (2007) and Flavián and Guinalíu (2006a) have taken into account security and privacy as variables that are part of a second-order construct that influences in the online trust, but they do not incorporate them as a dimension. Neither do Aldas, Ruiz, Sanz and Lassala (2011) consider channel security as a dimension of trust; these authors consider it as a second-order construct called perceived risk. Other authors, such as Sohn and Tadisina (2008), incorporate the variable trust in the e-service quality scale. Nevertheless, we should point out that the privacy dimension has a recognized limitation.

For management purposes, the obtained results suggest that bank managers should invest in providing reliability and security in the Internet channel.

Particularly, if these companies want to gain the trust of their users, they should be, first, honest in their actions. In our context of study, they could take some measures, such as to instantly update the customers' information that it would be an accurate reflection of reality, to provide transparency of the rates that will be applied, and to make truthful and accurate communications.

Second, they must also assume a benevolent character when making business decisions. For instance, they could develop websites with useful information and a simple and intuitive navigation structure that does not lead to mistake; make communications that do not omit relevant information to the decision making process; inform accurately and in an understandable language about the potential risks, restrictions and consequences; or enable a common space in the website where users can express their opinions and comments (Cheung \& Lee, 2006), it would also improve the decision making. These measures might imply, to some extent, that the balance of power would be equilibrated, by building a relationship based on cooperation with the consumer.

Third, our results also suggest managers must transmit to users that the firm is competent. To achieve it, they could use a quality website with a professional appearance (Cheung \& Lee, 2006) since it might reduce the disadvantage of impersonality that the own website has (Yousafzai, 2005). Because, as this author suggests, it provides " a solid feel, and clear navigation conveys respect for customers and an implied promise of good service". Cheung and Lee (2006) advise that professional appearance involves: ease of navigation, correct grammar and spelling, accurate and complete information, and a good graphic design. Moreover, they could offer financial products and/or services more appropriate to the needs of users, since they may use the better knowledge of the customer that online channel gives.

Forth, in order to response to insecurity, the firm could employ different mechanisms that allow the authentication of each partner and the safety access (for example, the digital signature, key authentication, coordinate cards, electronic ID, certificates of a safe connection, secure passwords and so on); making an explicit mention in the website about the use of security elements, as Mukherjee and Nath (2003) or Cheung and Lee (2006) suggest or; using certificates such as TRUSTe, BBBOnline, Verisign, and so on, since, as Benassi (1999) suggest, they lead online customers to have more willingness to provide personal information (Kuchinskas, 2003). It could be useful also to send instant communications to the user when an online connection has been done, indicating hour, day and access channel.

Finally, regarding privacy, managers could adopt several measures to treat appropriately all private data that are 
collected in the financial relationship. For instance, they could create a specific privacy policy (Wu, Huang, Yen \& Popova, 2012). This policy should allow to the consumer to control his/her personal information all the time (Mukherjee \& Nath, 2003), and, this results in the recognition that he/she has the property of the data that are in the Internet (Yousafzai, Pallister, Foxall \& Gordon, 2003). They could justify, in this privacy policy, what type of data will be required to complete the transaction, how data will be used, which entity will manage them, and which entity should be contacted whether user want to rectify or cancel his/her registration in the database; and whether data would be transferred or sold. And/or they could communicate the privacy policy to the user (Yousafzai, Pallister, Foxall \& Gordon, 2003).

\section{LIMITATIONS}

The major limitation of the study is the composition of the sample, particularly, the sampling procedure that has been selected: non probabilistic and for convenience (snowball). Despite not being a method with good statistical properties, AIMC (2008) qualifies this method as appropriate to the electronic context because of the impossibility of accessing to a suitable framework. Nevertheless, this situation should be considered regarding the generalizability of the results, its inference, and its prediction about the population. A second limitation is the possible omission of relevant dimension and indicators when approximate the measurement models, such as the failure to include a broader set of indicators in the construct of first-order privacy that, explicitly, picks up the entire concept. Accordingly, we suggest the need to develop new research containing the precise indicators conceptually. We also recognize the lack of verification of the nomological validity as a limitation. In subsequent studies, this could be reviewed through a structural model in which quality of service is inserted as a precursor variable of online trust (Sultan \& Mooraj, 2001; Harris \& Goode, 2004) or satisfaction (Reichheld \& Schefter, 2000; Shankar, Smith \& Rangaswamy, 2003; Harris \& Goode, 2004) and loyalty (Luarn \& Lin, 2005; Chouk \& Perrien, 2004; Harris \& Goode, 2004) as consequential variables of online trust. Another limitation of this study is its national scope, Spain. Additional research might use other countries for greater generalizability. Finally, one limitation is the cross-sectional research design employed that leads to conclude in a specific situation and environmental circumstances, but it may not be applicable under different conditions.

\section{REFERENCES}

Aimc (Asociación para la Investigación de Medios de Comunicación). (2008). Navegantes en la Red. 10 $\underline{a}$ Encuesta AIMC a Usuarios de Internet. Retrieved from: www.aimc.es.

Alcaide, J. C. \& Soriano, C. (2005). Marketing bancario relacional. McGraw-Hill Interamericana de España, S.A.U. Madrid.

Aldas-Manzano, J, Ruiz-Mafe, C, Sanz-Blas, S. \& Lassala-Navarré, C. (2011). Internet banking loyalty: evaluating the role of trust, satisfaction, perceived risk and frequency of use. The Service Industries Journal, 31(7), 1165-1190.

Alén, M. E. (2003). Análisis de la calidad de servicio percibida en los establecimientos termales: conceptualización, medición y relación con otras variables de marketing. Tesis doctoral en Marketing turístico. Universidad de Vigo.

Anderson, J. C. \& Gerbing, D. W. (1988). Structural equation modeling in practice: a review and recommended two-step approach. Psychological Bulletin, 103 (3), 411-423.

Anderson, J. C. \& Narus, J. A. (1990). A model of distributor firm and manufacturer firm working partnerships. Journal of Marketing, 54(1), 42-58.

Bagozzi, R. P, YI, Y. \& Phillips, L. W. (1991). Assessing construct validity in organizational research. Administrative Science Quarterly, 36(3), 421-458.

Belanger, F, Hiller, J. S. \& Smith, W. J. (2002). Trustworthiness in electronic commerce: the role of privacy, security, and site attributes. Journal of Strategic Information Systems, 11(3-4), 245-270.

Benassi, P. (1999). TRUSTe: an online privacy seal program. Communications of the ACM, 42(2), 56-59.

Bhattacherjee, A. (2002). Individual trust in online firm: scale development and initial test. Journal of Management Information Systems, 19(1), 211-241.

Bitner, M. J, Zeithaml, V. A. \& Gremler, D. D. (2010). Technology's impact on the gaps model of service quality. In Maglio Paul P, Kieliszewski Cheryl A, \& Spohrer James C. (Eds). Handbook of Service Science: Research and Innovations in the Service Economy. New York: Springer, pp. 197218. DOI 10.1007/978-1-4419-1628-0_10.

Blomqvist, K. (1997). The many faces of trust, Scandinavian Journal of Management, 13(3), 271-286.

Bravo, R, Montaner, T. \& Pina, J. M. (2007). La imagen corporativa de las entidades financieras: formación e impacto en el consumidor. XIX Encuentro de Profesores Universitarios de Marketing, Vigo. Ed. ESIC, Madrid, p. 202.

Carbó, S. (2004). Diez hechos estabilizados del sector bancario en España (1980-2004). Papeles de Economía Española, 100(1), 232-245

Casaló, L. V, Flavián, C. \& Guinalíu, M. (2007). The role of security, privacy, usability and reputation in the development of online banking. Online Information Review, 31(5), 583-603.

Cheung, M. K. \& Lee, K. O. (2006). Understanding consumer trust in internet shopping: a multidisciplinary approach. Journal of the American Society for Information Science and Technology, 57(4), 479-492.

Chouk, I. \& Perrien, J. (2004). Consumer trust towards an unfamiliar web merchant: a signaling approach. Actas de la $33^{\mathrm{a}}$ EMAC Conference, Murcia, mayo, pp. 1-6.

Coulter, K. \& Coulter, R. (2002). Determinants of trust in a service provider: the moderating role of length of relationship. Journal of Services Marketing, 16(1), 35-50. 
Crosby, L. A, Evans, K. R, \& Cowles, D. (1990). Relationship quality in services selling: an interpersonal influence perspective. Journal of Marketing, 54(3), 68-81.

Dabholkar, P. A. (1996). Consumer evaluations of new technology-based self-service options: an investigation of alternative models of service quality. International Journal of Research in Marketing, 13(1), 29-51.

Das, T. K. \& Teng, B. S. (2004). The risk-based view of trust: a conceptual framework, Journal of Business and Psychology, 19(1), 85-116.

Doney, P. M. \& Cannon, J. P. (1997). An examination of the nature of trust in buyer-seller relationships. Journal of Marketing, 61(2), 35-51.

Flavián, C. \& Guinalíu, M. (2007). Un análisis de la influencia de la confianza y del riesgo percibido sobre la lealtad a un sitio web: el caso de la distribución de servicios gratuitos. Revista Europea de Dirección y Economía de la Empresa, 16(1), 159-178.

Flavián, C. \& Guinalíu, M. (2006a). Consumer trust, perceived security and privacy policy. Three basic elements of loyalty to a web site. Industrial Management \& Data Systems, 106(5), 601-620.

Flavián, C. \& Guinalíu, M. (2006b). La confianza y el compromiso en las relaciones a través de Internet. Dos pilares básicos del marketing estratégico en la red. Cuadernos de Economía y Dirección de Empresa, (29), 133-160.

Flavián, C, Guinalíu, M. \& Torres, E. (2006). How bricks-and-mortar attributes affect online banking adoption. International Journal of Bank Marketing, 24(6), 406-423.

Fornell, C. \& Larcker, D. F. (1981). Evaluating structural equation models with unobservable variables and measurement error. Journal of Marketing Research, 18(1), 39-50.

Friedman, B, Kahn, P. \& Howe, D. C. (2000). Trust online. Communications of the ACM, 43(12), p. 34-40.

Ganesan, S. (1994). Determinants of long-term orientation in buyer-seller relationships. Journal of Marketing, 58(2), 1-19.

Garrido, A. (2007). Sistema financiero. In García, J. L, \& Myro, R. (Dir.). Lecciones de Economía Española. Editorial Aranzadi, S. A. (8ª edición), Navarra.

Gefen, D. (2000). E-commerce: the role of familiarity and trust. The International Journal of Management Science, 28(6), 725-737.

Gefen, D, Karahanna, E. \& Straub, D. W. (2003). Trust in TAM in online shopping: an integrated model. MIS Quarterly, 27(1), 51-90.

Gefen, D. \& Straub, D. W. (2004). Consumer trust in B2C e-Commerce and the importance of social presence: experiments in e-Products and e-Services. Omega - The International Journal of Management Science, $32(6), 407-424$.

Gerrard, P. \& Cunningham, J. B. (2003). The diffusion of Internet banking among Singapore consumers. The International Journal of Bank Marketing, 21(1), 16-28.

Geyskens, I, Steenkamp, J. B. \& Kumar, N. (1998). Generalizations about trust in marketing channel relationships using meta-analysis International Journal of Research in Marketing, 15(3), 223-248.

Geyskens, I, Steenkamp, J-B. E. M. \& Kumar, N. (1999). A meta-analysis of satisfaction in marketing channel relationships. Journal of Marketing Research, 36(2), 223-238.

Grabner-Kraüter, S. (2002). The role of consumers trust in online shopping, Journal of Business Ethics, 39(1-2), 43-50.

Grabner-Kraüter, S. \& Faullant, R. (2008). Consumer acceptance of internet banking: the influence of internet trust. International Journal of Bank Marketing, 26(7), 483-504.
Grewal, D, Lindsey-Mullikin, J. \& Munger, J. (2003). Loyalty in e-tailing: a conceptual framework. Journal of Relationship Marketing, 2(3-4), 31-49.

Gundlach, G. \& Murphy, P. E. (1993). Ethical and legal foundations of relational marketing exchanges. Journal of Marketing, 57(4), 35-46.

Hair, J. F, Anderson, R. E, Tatham, R. L. \& Black, W. C. (1999). Análisis multivariante. Prentice Hall. Madrid.

Harridge-March, S. (2006). Can the building of trust overcome consumer perceived risk online. Marketing Intelligence \& Planning, 24(7), 746-761.

Harris, L. C. \& Goode, M. H. (2004). The four levels of loyalty and the pivotal role of trust: a study of online service dynamics. Journal of Retailing, 80(2), 139-158.

Jarvenpaa, S. L, Tractinsky, N. \& Vitale, M. (2000). Consumer trust in an Internet Store. Information Technology and Management, 1(1-2), 45-71.

Jöreskog, K. G. \& Sörbom, D. (1986). Advances in factor analysis and structural equation models. Ed. Abt Associates. Cambridge.

Keeney, R. L. (1999). The value of internet commerce to the customer. Management Science, 45(4), 533-542.

Kini, A. \& Choobinech, J. (1998). Trust in electronic commerce: definition and theoretical considerations. In: Proceeding of the thirty-first Hawaii International Conference on System Sciences (HICSS), Maui, HI, January, pp. 51-61.

Kline, R. B. (2011). Principles and practice of structural equation modeling, Third Edition, 3rd ed. The Guilford Press. New York..

Kolsaker, A. \& Payne, C. (2002). Engendering trust in e-Commerce: a study of gender-based concerns. Marketing Intelligence \& Planning, 20(4), 206-214

Kuchinskas, S. (2003). Trust issues loom over E-commerce. Internetnews.com. Retrieved December 2, 2003, from http://boston.internet. com/news/article.php/3115091

Larzelere R. E. \& Huston, T. L. (1980). The dyadic trust scale: toward understanding interpersonal trust in close relationships. Journal of Marriage and the Family, 42(3), 595-604.

Lee, M. K. O. \& Turban, E. (2001). A trust model for consumer Internet shopping International Journal of Electronic Commerce, 6(1), 75-91.

Lévy, J-P. (2001). Modelización y programación estructural con AMOS. Instituto Superior de Técnicas y Prácticas Bancarias. Madrid.

Lévy, J-P, \& Varela, J. (2003). Análisis multivariable para las Ciencias Sociales. Pearson Educación, S.A. Madrid.

Luarn, P. \& Lin, H-H. (2005). Toward an understanding of the behavioral intention to use mobile banking. Computers in Human Behavior, 21(6), 873-891.

Luque, T. (2000). Técnicas de análisis de datos en investigación de mercados. Pirámide. Madrid.

Meuter, M. L, Ostrom, A. L, Roundtree, R. I. \& Bitner, M. J. (2000). Self-service technologies: understanding customer satisfaction with technology-based service encounters. Journal of Marketing, 64(3), 50-64.

Mukherjee, A. \& Nath, P. (2003). A model of trust in online relationship banking. International Journal of Bank Marketing, 21(1), 5-15.

Novak, T. P, Hoffman, D. L. \& Yung, Y. (2000). Measuring the customer experience in online environments: a structural modeling approach. Marketing Science, 19 (1), 22-42.

Oliver, D, Livermore, C. R. \& Farag, N. A. (2009). An explanatory model of self-service on the internet. In Oliver, D., Livermore, C, \& Sudweeks, $\mathrm{F}$, (Eds.). Self-service in the internet age: expectations and experiences. Springer. New York, pp. 257-274. 
Parasuraman, A, Zeithaml, V. \& Malhotra, A. (2005). E-S-QUAL: A multiple-item scale for assessing electronic service quality. Journal of Service Research, 7(3) 213-233.

Pavlou, P. A. (2003). Consumer acceptance of electronic commerce: integrating trust and risk with the technology acceptance model. International Journal of Electronic Commerce, 7(3), 101-134.

Pavlou, P. A. \& Fygenson, M. (2006). Understanding and predicting electronic commerce adoption: an extension of the theory of planned behavior. MIS Quarterly, 30(1), 115-143.

Pérez, F. \& Maudos, J. (2001). La eficiencia del sector bancario español en el contexto Europeo. Economistas, (89), 63-70.

Ramón, M. A. \& Martín, E. (2007). Estudio del desarrollo de la confianza considerando diferentes contextos de riesgo. XIX Encuentro de Profesores Universitarios de Marketing, Vigo. Ed. ESIC. Madrid, pp. 180

Ranganathan, C. \& Ganapathy, S. (2002). Key dimensions of business to consumer web sites. Information \& Management, 39(6), 457-465.

Reichheld, F. F. \& Schefter, P. (2000). E-loyalty: your secret weapon on the web. Harvard Business Review, 78(4), 105-113.

Riegelsberger, J, Sasse, A. M. \& McCarthy, J.D. (2005). The mechanics of trust: a framework for research and design. International Journal of Human-Computer-Studies, 62(30), 381-422.

Rotchanakitumnuai, S. \& Speece, M. (2003). Barriers to internet banking adoption: a qualitative study among corporate customers in Thailand. International Journal of Bank Marketing, 21(6), 312-323.

Roy, M, Dewit, O. \& Aubert, B. (2001). The impact of interface usability on trust in web retailers. Internet Research, 11(5) 388-398.

Ruiz, A. V, Izquierdo, A. \& Calderón, E. (2007). Actitudes hacia internet, riesgo percibido y confianza: su influencia sobre la compra de pernoctaciones hoteleras. In: Conocimiento, innovación y emprendedores: camino al futuro. Ayala Calvo, J. C (Coord). Ed. Universidad de La Rioja. España.

Shankar, V, Smith, A. K. \& Rangaswamy, A. (2003). Customer satisfaction and loyalty in online and offline environments, International Journal of Research in Marketing, 20(2), 153-175.
Sohn, C. \& Tadisina, S. K. (2008). Development of e-service quality measure for internet-based financial institutions. Total Quality Management, 19(9), 903-918.

Steiger, J. H. (1990). Structural model evaluation and modification: an interval estimation approach. Multivariate Behavioral Research, 25(2), 173-180.

Suh, B. \& Han, I. (2003). The impact of customer trust and perception of security control on the acceptance of electronic commerce. International Journal of Electronic Commerce, 7(3), 135-161.

Sultan, F. \& Mooraj, H. A. (2001). Designing a trust-based e-business strategy. Marketing Management, 10 (4), 40-44.

Torres, E, Manzur, E, Olavarrieta, S. \& Barra, C. (2009). Análisis de la relación confianza-compromiso en la banca en internet. Revista Venezolana de Gerencia, 14(47), 371-392.

Truste. (2003). Identity theft and spam will deter online shopping this holiday season. Press release of Truste. Cited in: Flavián, C, \& Guinalíu, M. (2006a). Consumer trust, perceived security and privacy policy. Three basic elements of loyalty to a web site. Industrial Management \& Data Systems, 106(5), 601-620.

Udo, G. (2001). Privacy and security concerns as major barriers for e-commerce: a survey study. Information Management \& Computer Security, 9(4), 165-174.

Walczuch, R. \& Lundgren, H. (2004). Psychological antecedents of institution-based consumer trust in e-retailing. Information \& Management, 42(1), 159-177.

Wu, K. W, Huang, S. Y, Yen, D. C. \& Popova, I. (2012). The effect of online privacy policy on consumer privacy concern and trust. Computers in Human Behavior, 28(3), 889-897.

Yoon, S. J. (2002). The antecedents and consequences of trust in on-line purchase decisions. Journal of Interactive Marketing, 16(2), 47-63.

Yousafzai, S. Y. K. (2005). Internet banking in the UK: a customer behaviour perspective. Doctoral dissertation. Cardiff University.

Yousafzai, Y, Pallister, G, Foxall, G. \& Gordon, R. (2003). A proposed model of e-trust for electronic banking. Technovation, 23(11), 847-860. 